\title{
Repositioning science education in Nigerian colleges of education through Public-Private Partnership (PPP)
}

\author{
Aina, Jacob Kola ${ }^{1}$, Akintunde, Zacchaeus Taiwo ${ }^{2}$ \\ ${ }^{1}$ Physics Department College of Education (T) Lafiagi, Kwara State, Nigeria \\ ${ }^{2}$ Physic Department Oyo State College of Agriculture, Igboora, Oyo State, Nigeria
}

\section{Email address:}

akoja64@gmail.com(Aina, J. K.)

\section{To cite this article:}

Aina, Jacob Kola, Akintunde, Zacchaeus Taiwo. Repositioning Science Education in Nigerian Colleges of Education through PublicPrivate Partnership (PPP). Science Journal of Education. Vol. 1, No. 5, 2013, pp. 64-67. doi: 10.11648/j.sjedu.20130105.13

\begin{abstract}
This is a review paper on using Public-Private Partnership (PPP) to reposition science education in Nigerian colleges of education. The paper looked at science education as the study of biology, chemistry or physics along with principle and method of education. Public-private partnership was viewed as voluntary arrangement between nongovernmental organization and government to execute or jointly carry out a project with the aim of sharing the profits and bear any involving risk together. Highlight of poor situation of science education in Nigerian colleges of education due to corruption and other factors were discussed in this paper. Practices of PPP in some countries and the benefits in PPP including what science education may gain from PPP were highlighted in the paper. Recommendations were suggested at the end based on the conclusion of the paper.
\end{abstract}

Keywords: Education, Science Education, Partnership, Entrepreneurship Education

\section{Introduction}

Science education is a field of study that combines biology, chemistry or physics with education in any higher institution of learning in Nigeria. Study of biology, chemistry or physics without principle and method of education is not science education

The importance of science education cannot be overemphasized in a growing technology like ours in Nigeria. Through science education an individual can become self employed [15]; it helps in Information and Communication Technology [1]; lead to several scientific fields and professions like engineering, manufacturing, mining and construction industries [13]

However, science education in Nigeria has not been able to rise to its full potential because of several factors stymieing its development. According to [3], science teachers and poor laboratories are problems of science education in Nigeria. Corruption, insecurity, political and economic factors are the banes of functional science education in the country [1]

The current position of science education is poor due to the aforementioned factors especially in Nigeria Colleges of Education.

Several efforts had been made to rescue the situation which seems not to have yielded any meaningful fruit; that is why this paper is looking at the option of repositioning it through Public-Private Partnership (PPP) in education.

The paper will look at the meaning of science education and PPP; current position of science education in Nigeria; benefits of PPP; conclusion and suggestions for repositioning science education through PPP.

\section{Science Education}

Science Education is the study of biology, chemistry or physics together with principle and method of education [1]. National Commission for Colleges of Education (NCCE), a body coordinating colleges of education programme in Nigeria allows biology, chemistry or physics to be combined with other subjects like mathematics, computer or integrated sciences. This does not make mathematics and computer science to be science education instead we have mathematics education and educational technology. Since integrated science is integration of biology, chemistry and physics, understandably, it could be incorporated into science education. The only problem with integrated science is that not many universities offer it beyond first degree in Nigeria.

It is mandatory for all students to study education with 
biology, chemistry or physics; studying biology, chemistry or physics alone or combined with any subject without education is not science education [3].

\section{Meaning of PPP}

History reveals it that in Africa, communities are willingly collaborating together in achieving common goals, sharing profits and bearing the risks involved together. Individuals from different profession can willingly reach a compromise to agree on working together in a project with the aim of sharing profits and bear any risk involved in the project.

PPP therefore can be define as a voluntary arrangement between non-governmental organization and government to execute or jointly carry out a project with the aim of sharing the profits and bear any involving risk together.

PPP can be looked at as a stewardship model whereby the private sector takes a more aggressive role in aspects of the project from which it had previously been excluded in the usual procurement approach, like design, financing, operations and maintenance. [5]

PPP is a well established methodology for procuring public works projects. When private sectors are incorporated into expertise public works projects, efficiency, and innovation in business, risk sharing, financing, and even the quality of public and facilities are uplifted [7].

PPP describes a relationship in which public and private resources are put together in achieving a goal or set of goals mutually beneficial to both the private entity and the public [16].

Public-Private Partnership in Education (PPPE) therefore will be a relationship in which the public (government) and private resources are voluntarily put together mainly for achieving educational goals.

Education is a capital intensive programme and according to [4], it is a power and vital instrument for national development. [10] said for a man to be able to articulate himself and for full achievement education is very necessary. Therefore access to functional education should not be left in the hand of government alone especially in Nigeria.

Government alone cannot bear the burden of functional education in Nigeria; there is that need for private sectors to be more actively involved. Individuals and nongovernmental agencies have a vital role to play in PPPE to ensure quality and functional education. There are lots of risks involved in education leading to wastages in educational system of the nation; since government is the major or only active actor in the sector it bear the risk alone. Involvements of other actors in the sector will lessen the risks and perhaps curtail the wastages.

[7] believed that, the private sector is more efficient in asset procurement and service delivery and as a result it is to the government's advantage to share the associated risks in education with the private sector. [11] opined that PPP helps government to develop and expedite the PPP market and at the same time protecting the public interest.

\section{Current Situation of Science Education in Nigeria Colleges of Education}

Science education in colleges of education in Nigeria is not in good position when view in the light of the National Policy on Education. Government has objectives for each of the three core science subjects that must be achieved in the course of study.

The kind of training currently going on in colleges of education can never achieve science education objectives in secondary schools because teachers who are to lay the foundation of science teaching in junior secondary school are not well trained.

Corruption is the bane of functional science education in Nigerian colleges of education. Corruption show its face in all facets of Nigeria society supported by a statement credited to the Nigerian President in a national news paper very recently that "Nigerians encourage corruption" [14].

Individuals and government create room for and take part in corruption and this is seriously affecting science education in colleges of education.

Staff are corrupt in discharging their duties; both academic and non academic alters students scores and records for money; they are not committed to serious academic work and yet received salary and allowances.

Frequent industrial disharmony between workers and their employers (government) resulting into closure of the colleges paralysis academic activities. This does not allow students to fully concentrate on their learning and eventually prolong their years of graduation. For instance, biology education students sometimes uses live animals for project and practical that need to be monitored for certain period of time; forcing students out of the school because of industrial action will affect this project or this practical work.

Cultism is very rampart in colleges of education nowadays as feared by [2] that cultists have made Nigerian higher institutions become a place of worry to everybody. Cult's activities are very difficult to curtail because of staff involvement that may involve some heads of the institutions themselves.

Cultism has disrupted academic programmes of tertiary institutions in Nigeria in many ways; lecturers do their work with fear because of cultist; serious one among the students are no more committed to their studies due to cult activities; institutions are closed down indefinitely and academic activities paralyzed for long period because of cult embarrassment in the colleges.

Examination malpractice has taken footholds in colleges of education in the country as supported by [6] that, even in teachers training institutions this is being practiced. Students don't read any more and they want to pass by all means resulting into all forms of examination malpractices. 
Staff of institutions who has lost their dignity also participates in this ugly act because of wealth. It has become very difficult to conduct any free and fair examination in these institutions because of examination malpractices. [9] in her paper on conducting examinations in Nigeria universities: A manager's perspective, worried at the way examination malpractice increases in higher institutions.

College management has lost their vision of being in the academic community because they want to make money; they have no control over the workers; they mismanage fund meant for equipment and chemical. The resultant effect of this is disruption of academic activities in the college.

Government appointment of Governing Council to monitor the affairs of colleges of education would have been good if they are performing well but the story is different in most colleges in Nigeria.

Most members of this governing council have turned their colleges to gold field where they make fortune against the purpose of their appointments. The presence of governing council in colleges of education has turned to a curse rather than blessing because of their nefarious activities. However, there may be some good ones but majority are bad.

They award contracts to themselves and never execute it or poorly executed: employed unqualified staff who are their relatives: divert money meant for science equipment and chemical to their personal accounts: called for council meeting frequently because of sitting allowances; each time they have meeting they are never bothered if salary of staff are not paid or other academic activities stop just because of the huge amount of money their meeting will engulf.

Some chairmen of this council have taken over day to day running of the college from the college management. The question that concern members of academic community is asking is "can't college survive without governing council'?

The government goofed by appointing this council into the system because most of them are politicians and school dropout who knew nothing about academic.

They did all these with impunity because government who appointed them is not sincere in the appointment since it was done possibly to compensate them for supporting their election. Government is silent when any of their corrupt activities got to them; their silence could mean tacit approval of this council.

\section{Benefits of PPP}

PPP had been practiced in many countries of the world in education, health and transportation sectors with good results. If genuinely adopted in Nigeria for the sake of our dying science education there is possibility of recording better success.

In Jamaica the Barbados Institute of Management and Productivity (BIMAP) in 1972 collaborated with the government of Barbados and the private sector to transform Jamaica education [8], PPP helped Jamaican school system in the area of technological training and e-learning as pointed out by [8]. Further suggested that PPP must be flexible to the changing needs of the economic environment and the partners; it must also be free from the bureaucratic control.

In Canada PPP was used in health care system and the result was amazing however, there is the need to adequately address public opinion with respect to the transfer of risk involved. Australia and South Africa have practiced PPP in different ways in order to accelerate and put priority on infrastructure projects in their different countries.

Going by the examples cited above PPP can equally work in repositioning science education in Nigeria colleges of education if the government is serious about it.

Financing education should be taken serious by every government and that is why every government should make education a priority as said by a state governor in a Nigerian news paper recently [12]. The private sectors would be willing to voluntarily partner with the government when that seriousness is there and the result will be great.

The huge money being spent by the government on science equipment will be reduced once there is partnership as earlier observed by [5] that key benefit of PPP is cost reduction.

There are lots of wastages in government venture especially in education due to corruption and lack of sincere monitoring. PPP will ensure sincere and proper monitoring of procurement of science equipment and reduction in corrupt practices associated with constructions of laboratories and science workshops.

Award of contracts will be properly monitored to ensure good delivery since education affair is no longer only in the hands of government. No non-governmental agency or individuals would invest money into a project and go to sleep without adequate monitoring to ensure success.

Recruitment of workers into colleges of education will be on merit once government partners with the private sector in education. Banks and companies employed best personnel to ensure efficiency; same will be replicated in schools once there is PPP.

Appointment of governing council will not be left in the hand of government to appoint politicians who have no good academic certificate; this appointment will be done jointly by the government and the private partners. In view of this, professionals will be appointed and they will offer their expertise ideas to move science education forward.

Industrial disharmony is not so rampart in private sectors as in education because of importance they placed on human relation; human relation is very poor in government establishments. No good Manager or Chief Executive of an organization will watch his or her workers embark on strike for days without concern as done in colleges of educations.

Since risks are shared in PPP all efforts will be put in place to ensure all segments of science education in the 
colleges of education is well monitored. Staff and students discipline will be improved; there is high level of discipline in private institutions compare to the public schools.

The popular saying that "government work is no man's work" cannot hold in PPP; both employers and employees are working round the clock to ensure high percentage of efficiency and low risk involvement in PPP.

\section{Conclusion}

In the light of the foregoing, the current position of science education in Nigerian colleges of education is worrisome and need a well repositioning to avert its total collapse. Considering examples of PPP in other nations of the world this paper considers it necessary too to reposition science education through PPP. Numerous benefits of PPP have been highlighted in this paper such as reduction in cost of education. In view of this conclusion the following recommendations are suggested for repositioning science education through PPP:

- Awareness of PPP should be created among stakeholders in science education

- Non governmental agencies and individuals should be willing to partner with government to move Nigerian educational system forward especially science education

- The government of Nigeria should be sincere in governance so as to encourage PPP

- Though partnership is voluntary but government should initiate policies to make it very easy for PPP

- Government should ensure all administrative bureaucracy that may act as bottlenecks to PPP are removed or minimized

- There should be workshops, seminars and conferences on PPP where stakeholders in science education can work together and know various benefits of PPP

- $\quad$ Principle of PPP should be introduced into science education curriculum as done for entrepreneurship education.

\section{References}

[1] J.K. Aina, Importance of Science education to national development and problems militating against its development, American Journal of Educational Research, vol.1, no. 7, 225-229. DOI:10.12691/education-1-7-2, 2013

[2] B.Y. Ajuwon, \&, F.A Oyeniyi Tackling the menace of cultism and indecent dressing: Implication for educational reform and consolidation. South-West Journal of Teacher Education, vol. 3, no. 1 pp.318-330, 2010.
[3] B.A. Awolaju, \&, O.O Akinloye Science education in democratized Nigeria: Challenges and the way forward, South-West Journal of Teacher Education, vol.3, no. 1, pp.615-622, 2010.

[4] O. Ayanwale .The role of informal civic education in educating the rural populace on democratic system of government, South-West Journal of Teacher Education, vol. 3 , no. 1 , pp. 26-40, 2010

[5] D. Barrows et al. Public-private partnership in Canadian health care: A case study of Brampton civic hospital. OECD Journal on Budgeting, vol.12, no. 1, pp.1-16, 2012.

[6] G. Bello. Analysis of examination malpractices perpetrated by pre-service teachers: A case study of Kwara State College of Education, Ilorin, Nigeria. Journal of Professional Teachers, vol.1, no. 2, pp.21-35, 2006.

[7] E. Cheung. Public Private Partnership (PPP) in Hong Kong (doctoral dissertation). Queensland university of Technology, Mach, 2009.

[8] A.S. Downes, Best practices of Public-Private Partnership on education and skill training in the Caribbean. Sir Arthur Lewis Institute of Social and Economic Studies University of the West Indies, Cave Hill Campus, BARBADOS, 2006.

[9] N.Y.S. Ijaya. Conducting examinations in Nigeria universities: A manager's perspective. Journal of Curriculum and Instruction, vol.6, no. 1\&2, pp.1-16, 2002

[10] A.O. Ikotun Adult education as weapon for self fulfilment in a democratized Nigeria, South-West Journal of Teacher Education, vol.3, no.1, pp.209-219, 2010.

[11] L. Istrate, and R. Puentes Moving forward on public private partnership: U.S and international experience with PPP units. Project on State and Metropolitan Innovation: BrookingsRockefeller, 2011.

[12] K. Ogundele and, E. Opara. Aliyu blast Wike over comments on education. The Punch, Retrieved www.punchng.cm/ [Accessed: 19-September-2013]

[13] E.O. Omosewo. Views of physics teachers on the need to train and retrain Physics teachers in Nigeria. African Research Review, vol.3, no. 1, pp. 314-325, 2009.

[14] I. Onuba. Nigerians encourage corruption. The Punch. Retrieved from www.punchng.cm/ [Accessed: 19September-2013]

[15] T, Owolabi, O. H. Akintoye and, S.A. Adeyemo Career prospect in physics education in quest towards entrepreneurial skill development. Research Journal of Social Sciences, vol.1, no. 6, pp1-5, 2011.

[16] L. Witters, R. Marom and S.A. Kurt. The role of publicprivate partnership in driving innovation. The Global Innovation Index, 2012. 